\title{
Effects of aqueous leaf extract of avocado (Persea americana) on total cholesterol, triacylglycerols, protein and haematological parameters in $\mathrm{CCl}_{4}$-intoxicated rats
}

\author{
B. I. C. Brai ${ }^{1 *}$, J. A. Falode ${ }^{1}$, R. A. Adisa ${ }^{2}$ and A. A. Odetola ${ }^{3}$
}

\begin{abstract}
Background: Avocado (Persea americana) is one of the plants widely used in ethnomedicine in Nigeria. The present study was aimed at investigating effects of aqueous Avocado (Persea americana) leaf extract on total cholesterol, triacylglycerols, protein and haematological parameters in carbon tetrachloride $\left(\mathrm{CCl}_{4}\right)$-intoxicated rats.

Methods: We evaluated the possible effects of pre-treatment with aqueous extract of Persea americana (AEPA) on protein, total cholesterol (T-CHOL), triacylglycerols (TAGs) and haematological parameters in Wistar male albino rats intoxicated with $\mathrm{CCl}_{4}$. Group 1 was the healthy control; group 2 rats were pre-treated with Reducdyn ${ }^{\circledast}(100 \mathrm{mg} / \mathrm{kg} /$ day) as a standard drug, groups 4 and 5 rats were pre-treated with AEPA at a dose of $100 \mathrm{mg} / \mathrm{kg}$ and $200 \mathrm{mg} / \mathrm{kg}$ per day respectively, the treatments were administered orally for 7 days. On the seventh day, rats in the treatment groups were injected with a fresh mixture of $\mathrm{CCl}_{4}$ and olive oil $(3 \mathrm{ml} / \mathrm{kg}, 1: 1 ; \mathrm{sc})$.

Results: Pre-treatment of rats with AEPA resulted in marked increase $(p<0.05)$ in total protein and reduction in TCHOL (19-34\%) compared to $\mathrm{CCl}_{4}$ alone. Also, there was significant decrease $(p<0.05)$ in serum TAG concentration when rats were pre-treated with $100 \mathrm{mg}$ and $200 \mathrm{mg} \mathrm{kg}^{-1}$ b. wt. AEPA. Similarly, AEPA provoked $(p<0.05)$ a lowering of T-CHOL and TAG levels and an increase in liver protein concentration in the rats. Administration of AEPA at both concentrations restored $(p<0.05)$ WBC count and ameliorated neutropenia and lymphocytosis caused by $\mathrm{CCl}_{4}$ intoxication.

Conclusion: These results suggest that AEPA could be protective against the development of fatty liver and might also be exhibiting the potential to prevent alterations in haematological parameters caused by $\mathrm{CCl}_{4}$ intoxication in rats.
\end{abstract}

Keywords: Persea americana, Total cholesterol, Triacylglycerols, Haematological parameters, Carbon tetrachloride $\left(\mathrm{CCl}_{4}\right)$

\section{Introduction}

The liver plays a pivotal role in drug and xenobiotic metabolism and is thus susceptible to attacks by these agents leading to liver injuries or damage. Injury to the liver results in several disorders including elevation in hepatic enzymes, steatosis (accumulation of triacylglycerols

\footnotetext{
* Correspondence: bartholomew.brai@fuoye.edu.ng

'Department of Biochemistry, Phytomedicine, Biochemical Pharmacology

and Toxicology Unit, Federal University, Oye, Ekiti, Nigeria

Full list of author information is available at the end of the article
}

in the liver), reduced $\beta$-oxidation of fatty acids, and necrosis [7].

Fatty degeneration of the liver (steatosis) resulting from $\mathrm{CCl}_{4}$ intoxication is attributed to an imbalance between lipid biosynthesis and degradation. It could also result from the failure of triacylglycerols to be transferred as VLDL from liver to the circulation [7, 38].

In the rats, a major metabolic defect induced by $\mathrm{CCl}_{4}$ intoxication appears to be inhibition of triacylglycerols release from the liver. This inhibition of outward transport would allow the accumulation of triacylglycerols 
within the liver and the development of fatty liver associated with $\mathrm{CCl}_{4}$ poisoning [16].

Plant-derived drugs and herbal formulations are obtained from natural sources and their use have been on the increase in many countries around the world. This is because they are usually viewed to be less toxic and free from serious side effects than the conventional synthetic drugs $[4,6,24]$.

Avocado (Persea americana) is one of the plants that have been widely used in ethno-medicine. In Nigeria, the leaf has various local names such as Ewé pia (Yoruba), Akwukwo Ube oyibo (Igbo), and Ganyen piya (Hausa).

Avocado leaves extracts have been reported to possess anti-inflammatory, antihypertensive/hypotensive, and hypoglycemic activities as well as vasorelaxant action and anticonvulsant effect [2, 3, 5, 14, 15, 26, 28]. Also, the leaf extracts of $P$. americana have been shown to be protective against cholesterol-induced hyperlipidemia in rats $[9,19]$.

The most abundant bioactive phytoconstituents of Avocado include phenolics, phytosterols, minerals, vitamins, and carotenoids [12, 27, 33]. These bioactive compounds have been shown to possess lipid-lowering, antidiabetic, cardioprotective, antiatherosclerotic activity [35].

Thus, the possible effects of aqueous AEPA on protein, total cholesterol (T-CHOL), triacylglycerols (TAGs) and haematological parameters in Wistar male albino rats intoxicated with carbon $\mathrm{CCl}_{4}$ were evaluated.

\section{Materials and methods}

\section{Plant material}

Fresh avocado leaves were collected from a cultivated plant in Ilupeju, Lagos. The leaves were authenticated at the Department of Botany, University of Lagos, and a voucher specimen (LUH 4199), was deposited at the herbarium of the department.

\section{Preparation of plant extract}

The leaves were air-dried, pulverized and the aqueous extract was prepared by loading the powdered leaves into a Soxhlet apparatus. The extraction lasted for $12 \mathrm{~h}$, and the extract solution was evaporated to dryness in a rotary evaporator at $40^{\circ} \mathrm{C}$ to obtain a residue labeled AEPA which was stored in clean vials until required.

\section{Experimental animals}

Thirty male Wistar strain albino rats (130-160 g), were purchased from the Animal House of Nigerian Institute of Medical Research (NIMR), Lagos. The rats were acclimatized for 1 week. and maintained under standard conditions of temperature $\left(23 \pm 2{ }^{\circ} \mathrm{C}\right)$ and $12 \mathrm{~h}$ light/dark cycle. The rats were treated with humane care, fed with a standard diet and water ad libitum.

\section{Experimental design}

Hepatoxicity was induced in the rats by subcutaneous injection of carbon tetrachloride as described by Wang et al. [37].

The albino rats were randomly divided into five treatment groups of six rats per group. Group 1served as healthy control. Groups 2, 3, 4, and 5 served as treatment groups. Group 2 rats received distilled water $(3 \mathrm{ml} / \mathrm{kg})$, Group 3 rats were pre-treated with Reducdyn ${ }^{\circ}(100 \mathrm{mg} /$ $\mathrm{kg} /$ day). Groups 4 and 5 rats were pre-treated with AEPA at a dose of $100 \mathrm{mg} / \mathrm{kg}$ and $200 \mathrm{mg} / \mathrm{kg}$ per day respectively. All the treatments were administered orally for 7 days. On the seventh day, rats in the treatment groups were subcutaneously injected with a fresh mixture of $\mathrm{CCl}_{4}$ and olive oil ( $3 \mathrm{ml} / \mathrm{kg}, 1: 1)$, 30 minutes after the administration of the last dose of the pre-treatment drug (Group 3), or extract Groups 4 and 5), or distilled water (Group 2). Rats in Group 1 were administered olive oil $(3 \mathrm{ml} / \mathrm{kg}$, sc). After $24 \mathrm{~h}$, the rats were sacrificed by cervical dislocation and blood samples collected by cardiac puncture into plain sterile tubes, allowed to coagulate and then centrifuged at $3000 \mathrm{rpm}$ for $10 \mathrm{~min}$., at $4{ }^{\circ} \mathrm{C}$. The serum obtained was stored at $-80^{\circ} \mathrm{C}$ pending analysis. Some of the blood samples were also dispensed into clean ethylene diamine tetra acetic acid (EDTA)-containing bottles for haematological investigation. Rat livers were quickly excised and perfused with chilled $1.15 \%(\mathrm{w} / \mathrm{v})$ potassium chloride $(\mathrm{KCl})$ solution to remove all traces of haemoglobin. The livers were blotted dry, weighed and used to prepare liver homogenates.

\section{Biochemical analysis}

Protein concentration was determined using the Bradford method which is based on the absorbance maximum of Coomassie Brilliant Blue G-250 at $595 \mathrm{~nm}$.

Total cholesterol (T-CHOL) and triacyglycerols (TAG), were measured using kits purchased from RANDOX Laboratories Ltd. (Crumlin, UK).

\section{Haematological parameters}

Haematological parameters including packed cell volume, hemoglobin concentration, white blood cell count, red blood cell count, eosinophils, lymphocyte and neutrophils counts, were measured using standard methods as described by Dacie and Lewis [10].

\section{Statistical analysis}

Results were expressed as mean \pm standard error of the mean (S.E.M). Differences between the groups were determined using one-way analysis of variance (ANOVA). Statistical significance of the difference of means was determined and indicated by $p$-values $\leq 0.05$. 


\section{Results}

Effect of pre-treatment with aqueous leaf extract of $P$. americana on serum total protein, total cholesterol and triacylglycerols in $\mathrm{CCl}_{4}$-induced hepatotoxicity in rats Serum total cholesterol, triacylglycerols and protein concentrations in rats pre-treated with AEPA and challenged with $\mathrm{CCl}_{4}$ are as presented in Table 1 . Serum T$\mathrm{CHOL}$ level was slightly raised (12\%) in $\mathrm{CCl}_{4}$-intoxicated rats compared to normal control rats. Pre-treatment with $100 \mathrm{mg}$ and $200 \mathrm{mg} \mathrm{kg}^{-1}$ b. wt. AEPA resulted in the lowering of $\mathrm{T}-\mathrm{CHOL}$ by $19 \%$ and $34 \%$ respectively while pre-treatment with $100 \mathrm{mg} \mathrm{kg}^{-1}$ b. wt. Reducdyn ${ }^{\odot}$ caused 52\% decrease in T-CHOL. Serum TAG concentration was markedly raised $(p<0.05 ; 113 \%)$ in $\mathrm{CCl}_{4}$ treated rats compared with healthy control. A significant reduction ( $\mathrm{p}<0.05 ; 65 \%$ and $64 \%$ of $\mathrm{CCl}_{4}$ control) in TAG concentration was observed when rats were pretreated with $100 \mathrm{mg}$ and $200 \mathrm{mg} \mathrm{kg}^{-1}$ b. wt. AEPA, respectively. Serum total protein concentration was significantly reduced $(p<0.05 ; 54 \%)$ in $\mathrm{CCl}_{4}$-treated rats. Pre-treatment with $100 \mathrm{mg}$ and $200 \mathrm{mg} \mathrm{kg}^{-1}$ b. wt. AEPA caused a significant increase $(p<0.05 ; 119 \%$ and $129 \%$, respectively) in serum protein compared to $\mathrm{CCl}_{4}$ control animals. However, the levels of T-CHOL, TAGs and protein in rats pre-treated with AEPA were not significantly different from the normal control.

\section{Effect of pre-treatment with aqueous leaf extract of $P$.} americana on liver total protein, total cholesterol and triacylglycerols in $\mathrm{CCl}_{4}$-induced hepatotoxicity in rats Liver protein, total cholesterol and triacylglycerol concentrations in $\mathrm{CCl}_{4}$-intoxicated rats and AEPA pre-treated rats are depicted in Table 2. Total cholesterol increased significantly $(p<0.05 ; 206 \%)$ in $\mathrm{CCl}_{4}$ control rats compared with healthy control. Pre-treatment with AEPA (100 $\mathrm{mg}$ and $200 \mathrm{mg} \mathrm{kg}^{-1}$ b. wt.) significantly reduced $(p<0.05 ; 57 \%$ and $58 \%$ respectively) T-CHOL concentration compared to $\mathrm{CCl}_{4}$ control. Liver TAG concentration was profoundly elevated $(p<0.05 ; 351 \%)$ by $\mathrm{CCl}_{4}$ administration compared to healthy control. Pre-treatment with $100 \mathrm{mg}$ and $200 \mathrm{mg} \mathrm{kg}^{-1}$ b. wt. AEPA provoked a reduction in liver TAG (50\% and 51\% respectively) compared to
$\mathrm{CCl}_{4}$. Total protein concentration was lowered by $18 \%$ following $\mathrm{CCl}_{4}$ intoxication and this was improved by pretreatment with AEPA and Reducdyn ${ }^{\oplus}$ up to $14 \%$ and $18 \%$ respectively. There was no significant difference $(p>0.05)$ in the observed protection by AEPA and Redcdyn ${ }^{\circ}$.

\section{Effect of pre-treatment with aqueous leaf extract of $P$. americana on peripheral blood smears in $\mathrm{CCl}_{4}$ - intoxicated rats}

Table 3 shows the levels of some haematological parameters observed in the experimental rats pre-treated with AEPA and intoxicated with $\mathrm{CCl}_{4}$. There was a nonsignificant decrease $(p>0.05)$ in the packed cell volume (7\%) and haemoglobin concentration (7\%) of $\mathrm{CCl}_{4}$ treated rats, respectively compared to healthy control. Also, total white blood cells (WBC) counts and neutrophils were significantly reduced $(p<0.05)$ while lymphocytes were increased by $\mathrm{CCl}_{4}$ administration compared to healthy control. Pre-treatment with $100 \mathrm{mg}$ and $200 \mathrm{mg} \mathrm{kg}^{-1} \mathrm{~b}$. wt. AEPA restored WBC counts while pre-treatment with 100 $\mathrm{mg} \mathrm{kg}^{-1}$ b. wt. AEPA only increased neutrophils and lowered lymphocytes counts. Similarly, AEPA at $200 \mathrm{mg}$ $\mathrm{kg}^{-1} \mathrm{~b}$. wt reduced packed cell volume and haemoglobin concentration by 12.5 and $19 \%$, respectively.

\section{Discussion}

Administration of $\mathrm{CCl}_{4}$ caused inhibition of protein synthesis manifested as decrease in both serum and liver total proteins compared with healthy control. This finding is similar to earlier reports by other workers [1, 22, 23, 36]. Inhibition of protein synthesis in the liver is primarily considered to bring about lowering of lipoprotein synthesis and accumulation of fat in the liver, resulting in the development of fatty liver [30]. It is also suggested that a decline in total protein content is a useful index of the severity of cellular dysfunction in chronic liver diseases [36]. Pretreatment with AEPA restored serum and liver total protein to near the levels in healthy controls. The restoration of total protein content in serum and liver of rats treated with AEPA is indicative of stimulation of protein synthesis. This could accelerate the regeneration process and the

Table 1 Effect of pre-treatment with aqueous leaf extract of $P$. americana on serum total protein, total cholesterol and triacylglycerols in $\mathrm{CCl}_{4}$-induced hepatotoxicity in rats

\begin{tabular}{llll}
\hline Treatment (Dose, $\mathrm{mg} / \mathrm{kg})$ & $\mathrm{T}-\mathrm{CHOL}(\mathrm{mg} / \mathrm{dl})$ & TAG $(\mathrm{mg} / \mathrm{dl})$ & Total Protein $(\mathrm{mg} / \mathrm{g}$ tissue) \\
\hline Control & $63.05 \pm 4.76$ & $59.65 \pm 3.96$ & $84.88 \pm 2.33$ \\
$\mathbf{C C l}_{\mathbf{4}}+$ AEPA (100) & $57.25 \pm 2.66^{\mathrm{b}}$ & $44.68 \pm 3.95^{\mathrm{a}}$ & $85.07 \pm 1.39^{\mathrm{a}}$ \\
$\mathbf{C C l}_{\mathbf{4}}+$ AEPA (200) & $46.57 \pm 7.10^{\mathrm{b}}$ & $46.28 \pm 6.67^{\mathrm{a}}$ & $89.11 \pm 1.85^{\mathrm{a}}$ \\
$\mathbf{C C l}_{4}+$ Reducdyn & $33.89 \pm 0.33^{\mathrm{a}}$ & $58.42 \pm 3.96^{\mathrm{a}}$ & $82.62 \pm 3.60^{\mathrm{a}}$ \\
$\mathrm{CCl}_{\mathbf{4}}$ & $70.79 \pm 8.95^{\mathrm{b}}$ & $126.94 \pm 11.63^{\mathrm{b}}$ & $38.79 \pm 4.91^{\mathrm{b}}$ \\
\hline
\end{tabular}

Values are expressed as means \pm SEM $(n=6)$

$\mathrm{T}$-CHOL Total cholesterol, TAG Triacylglycerol, $\mathrm{CCl}_{4}$ carbon tetrachloride, AEPA Aqueous extract of Persia americana

Values not sharing a common superscript differ significantly at $p<0.05$ 
Table 2 Effect of pre-treatment with aqueous leaf extract of $P$. americana on liver total protein, total cholesterol and triacylglycerols in $\mathrm{CCl}_{4}$-induced hepatotoxicity in rats

\begin{tabular}{llll}
\hline Treatment (Dose, $\mathrm{mg} / \mathrm{kg})$ & $\mathrm{T}-\mathrm{CHOL}(\mathrm{mg} / \mathrm{dl})$ & TAG $(\mathrm{mg} / \mathrm{dl})$ & Total Protein (mg/g tissue) \\
\hline Control & $36.95 \pm 8.93$ & $176.42 \pm 13.93$ & $44.96 \pm 0.73$ \\
$\mathbf{C C l}_{4}+$ AEPA (100) & $49.04 \pm 3.8^{\mathrm{b}}$ & $395.56 \pm 53.55^{\mathrm{a}}$ & $42.02 \pm 0.44$ \\
$\mathrm{CCl}_{4}+$ AEPA (200) & $47.73 \pm 7.98^{\mathrm{b}}$ & $388.11 \pm 31.05^{\mathrm{a}}$ & $40.80 \pm 0.72$ \\
$\mathrm{CCl}_{\mathbf{4}}+$ Reducdyn & $53.87 \pm 9.07^{\mathrm{b}}$ & $371.53 \pm 20.51^{\mathrm{a}}$ & $43.49 \pm 0.35$ \\
$\mathrm{CCl}_{4}$ & $113.13 \pm 8.50^{\mathrm{a}}$ & $795.50 \pm 41.2^{\mathrm{b}}$ & $36.77 \pm 0.54$ \\
\hline
\end{tabular}

Values are expressed as means \pm SEM $(n=6)$

$T$-CHOL Total cholesterol, TAG Triacylglycerol, $\mathrm{CCl}_{4}$ carbon tetrachloride, AEPA Aqueous extract of Persia americana

Values not sharing a common superscript differ significantly at $p<0.05$

production of liver cells as well as further elucidate its hepatoprotective activity.

Increases in the levels of cholesterol and TAGs were observed in serum and hepatic tissues. This confirms previous reports that $\mathrm{CCl}_{4}$ treatment provokes increase in cholesterol and TAGs levels in rat liver [18, 34, 36]. $\mathrm{CCl}_{4}$ increases the synthesis of fatty acids and TAGs from acetate. This could be due to the transport of acetate into the liver cell, resulting in increased substrate availability.

Also, it is postulated that the major metabolic defect induced by $\mathrm{CCl}_{4}$ intoxication to rats is inhibition of hepatic TAGs release. This inhibition of outward transport allows the accumulation of TAGs within the liver and the occurrence of fatty liver associated with $\mathrm{CCl}_{4}$ poisoning [16]. Intoxication with $\mathrm{CCl}_{4}$ has also been shown to increase the synthesis of cholesterol [7].

On the other hand, $\mathrm{CCl}_{4}$ reduces the hydrolysis of TAGs and $B$-oxidation of fatty acids thus, making more fatty acids available for esterification [20]. Disruption of $\beta$-oxidation of fatty acids in the mitochondrial causes microvesicular steatosis, typified by accumulation of tiny lipid vesicles in the cytoplasm of hepatocytes [13]. Owing to reduced mitochondrial oxidation, non-esterified fatty acids (NEFAs) build up in the liver and become esterified into TAG. Also, it has been shown that during $\mathrm{CCl}_{4}$ toxicity, fat from the peripheral adipose tissue is translocated to the liver and kidney leading to its accumulation [11]. It is suggested that an essential step in the outward transport of hepatic TAGs is the synthesis of lipoproteins at the endoplasmic reticulum by the utilization of TAG previously synthesized at another site. Damage to the endoplasmic reticulum during $\mathrm{CCl}_{4}$ intoxication inhibits lipoprotein synthesis. This may effectively decrease outward TAGs transport and results in the development of a fatty liver $[16,17,29,32]$. These factors could possibly explain the significant increase in hepatic TAGs observed in $\mathrm{CCl}_{4}$-intoxicated rats in this study. However, pretreatment with AEPA produced a substantial reduction in the elevated hepatic cholesterol and TAGs levels. This suggests that the extract prevented $\mathrm{CCl}_{4}$-induced hyperlipidaemia probably due to its hepatoprotective activity [8] in a mechanism that involves increase outward translocation of TAGs. $P$. americana has previously be shown to protect rats against cholesterol-induced hyperlipidemia by lowering total cholesterol, triglycerides and LDL, and increasing HDL levels $[9,19]$. Various mechanisms have been postulated for the antihypertriglyceridemic activity of medicinal plants including: inhibition of sterol regulatory element-binding transcription factor 1 (SREBP-1), antioxidant and anti-inflammatory activities, inhibition of 3-hydroxy-3-methylglutaryl coenzyme A (HMGCoA) reductase, inhibition of lipogenesis, inhibition of leptin secretion among others [25,31].

Administration of $\mathrm{CCl}_{4}$ alone caused leucopenia, neutropenia and lymphocytosis in the rats similar to the findings of Mandal et al. [21]. The administration of AEPA at a concentration of $100 \mathrm{mg}$ and $200 \mathrm{mg} \mathrm{kg}^{-1} \mathrm{~b}$. wt restored WBC count level by $99 \%$ and $85 \%$ respectively compared to $\mathrm{CCl}_{4}$ control rats. This finding therefore suggests that

Table 3 Effect of pre-treatment with aqueous leaf extract of $P$. americana on peripheral blood smears in $\mathrm{CCl}_{4}$ - intoxicated rats

\begin{tabular}{lllllllll}
\hline Treatment (Dose, $\mathrm{mg} / \mathrm{kg})$ & $\mathrm{WBC}$ & $\mathrm{PCV}$ & $\mathrm{Hb}$ & $\mathrm{N}$ & $\mathrm{L}$ & $\mathrm{M}$ & $\mathrm{E}$ & $\mathrm{B}$ \\
\hline Control & $8666.67 \pm 785.99$ & $36.08 \pm 1.54$ & $12.03 \pm 0.51$ & $45.60 \pm 8.15$ & $55.80 \pm 8.50$ & $0.20 \pm 0.20$ & $0 \pm 0$ & $0 \pm 0$ \\
$\mathbf{C C l}_{\mathbf{4}}+$ AEPA (100) & $8700.00 \pm 687.75$ & $38.67 \pm 3.25$ & $12.89 \pm 1.08$ & $33.50 \pm 6.48$ & $66.17 \pm 6.33$ & $0.33 \pm 0.21$ & $0 \pm 0$ & $0 \pm 0$ \\
$\mathbf{C C l}_{4}+$ AEPA (200) & $9683.33 \pm 656.97$ & $27.08 \pm 3.10$ & $9.77 \pm 0.88$ & $20.00 \pm 2.97$ & $77.60 \pm 1.12$ & $0.20 \pm 0.20$ & $0.40 \pm 0.40$ & $0 \pm 0$ \\
$\mathbf{C C l}_{\mathbf{4}}+$ Reducdyn & $10,066.67 \pm 635.96$ & $34.33 \pm 1.45$ & $11.61 \pm 0.64$ & $39.60 \pm 6.42$ & $60.20 \pm 6.37$ & $0.20 \pm 0.20$ & $0 \pm 0$ & $0 \pm 0$ \\
$\mathbf{C C l}_{4}$ & $4833.33 \pm 811.04$ & $33.50 \pm 1.70$ & $11.17 \pm 0.57$ & $22.60 \pm 2.66$ & $76.00 \pm 2.68$ & $0.60 \pm 0.40$ & $0.20 \pm 0.20$ & $0 \pm 0$ \\
\hline
\end{tabular}

All the values are presented as mean \pm S.E.M

WBC white blood cells $\left(10^{3} / \mu \mathrm{L}, P C V\right.$ packed cell volume (\%), Hb haemoglobin (g/dl), $N$ neutrophils (\%), $L$ lymphocytes (\%), $M$ monocytes (\%), $E$ eosinophils (\%), $B$ basophils (\%), $\mathrm{CCl}_{4}$ carbon tetrachloride, AEPA Aqueous extract of Persia americana 
AEPA has the potential to restore $\mathrm{CCl}_{4}$-induced alterations of haematological parameters in rats.

\section{Conclusion}

The increases in cholesterol and triacylglycerol provoked by $\mathrm{CCl}_{4}$ administration were considerably reduced by pre-treatment with AEPA. This suggests that AEPA could prevent $\mathrm{CCl}_{4}$-induced hyperlipidaemia and inhibit the development of fatty liver in the rats. Furthermore, AEPA exhibited the potential to prevent $\mathrm{CCl}_{4}$-induced leucopenia, lymphocytosis and other hematological related alterations in rats.

\section{Abbreviations}

AEPA: Aqueous extract of Persia americana; B: Basophils (\%); $\mathrm{CCl}_{4}$ : Carbon tetrachloride; E: Eosinophils (\%); Hb: Haemoglobin (g/dl); L: Lymphocytes (\%); M: Monocytes (\%); N: Neutrophils (\%); PCV: Packed cell volume (\%); TAG: Triacylglycerol; T-CHOL: Total cholesterol; WBC: White blood cells $\left(10^{3} / \mu \mathrm{L}\right.$

\section{Acknowledgements}

None.

\section{Authors' contributions}

BBIC conceived, designed and carried out the laboratory experiments, wrote the manuscript; ARA read and improved the manuscript; FJA read and prepared the manuscript for publication; OAA designed and supervised the work.

\section{Funding}

This is a self-sponsored research project, no funding whatsoever was received.

\section{Availability of data and materials}

Research data and materials can be provided on request.

\section{Ethics approval}

Animals were handled and used in accordance with the National Institute of Health guide for the care and use of laboratory animals (Washington (DC):

National Academies Press (US); 2011).

\section{Consent for publication}

All authors totally agreed to the publication of the research.

\section{Competing interests}

The authors declare that they have no competing interest.

\section{Author details}

${ }^{1}$ Department of Biochemistry, Phytomedicine, Biochemical Pharmacology and Toxicology Unit, Federal University, Oye, Ekiti, Nigeria. ${ }^{2}$ Department of Biochemistry, College of Medicine, Laboratories for Biomembrane and Cancer Research, University of Lagos, Lagos, Nigeria. ${ }^{3}$ Department of Biochemistry, University of Ibadan, Ibadan, Nigeria.

Received: 29 July 2019 Accepted: 26 February 2020

Published online: 05 March 2020

\section{References}

1. Abdel-Hamid NM. Diphenyl dimethyl Bicarboxylate as an effective treatment for chemical-induced fatty liver in rats. Afr J Biomed Res. 2006;9:77-81.

2. Adeboye JO, Fajonyomi MO, Makinde JM, Taiwo OB. A preliminary study on the hypotensive activity of Persea americana leaf extracts in anaesthetized normontensive rats. Fitoterepia. 1999:70:15-20.

3. Adeyemi $\mathrm{OO}, \mathrm{Okpo} \mathrm{SO}$, Ogunti $\mathrm{OO}$. Analgesic and anti-inflammatory effects of aqueous extract of leaves of Persea americana mill. (Lauraceae). Fitoterapia. 2002:73:375-80.

4. Annapurna A, Mahalakshmi D, Murali K. Antidiabetic activity of a polyherbal preparation (tincture of punchparna) in normal and diabetic rats. Indian J Exp Biol. 2001;39:500-2.

5. Antia BS, Okokon JE, Okon PA. Hypoglycemic activity of aqueous leaf extract of Persea americana mill. Indian J Pharmacol. 2005;37:325-6.
6. Bhattacharya SK, Satyan KS, Chakrbarti A. Effect of Trasina, an Ayurvedic herbal formulation, on pancreatic islet superoxide dismutase activity in hyperglycemic rats. Indian J Exp Biol. 1997;35:297-9.

7. Boll M, Weber LWD, Becker E, Stampfl A. Pathogenesis of carbon tetrachlorideinduced hepatocyte injury. Bioactivation of $\mathrm{CCl}_{4}$ by cytochrome P450 and effect on lipid homeostasis. Z Naturforsch. 2001;56c:111-21.

8. Brai BIC, Adisa RA, Odetola AA. Hepatoprotective properties of aqueous leaf extracts of Persea americana. Mill (Lauraceae) avocado against CCl4-induced damage in rats. Afr J Tradit Complement Altern Med. 2014;11(2):237-44.

9. Brai BIC, Odetola AA, Agomo PU. Hypoglycemic and Hypocholesterolemic potential of Persea americana leaf extracts. J Med Food. 2007;10(2):356-60.

10. Dacie JV, Lewis SM. Practical haematology 8th ed. London: Churchill Livingstone; 1995. p. 37-85.

11. Devarshi P, Kanase A, Kanase R, Mane S, Patil S, Varute AT. Effect of mandur bhasma on lipolytic activities of liver, kidney and adipose tissue of albino rat during $\mathrm{CCl}_{4}$-induced hepatic injury. J Biosci. 1986;10:227-34.

12. Dreher ML, Davenport AJ. Hass avocado composition and potential health effects. Crit Rev Food Sci Nutr. 2013;53:738-50.

13. Fromenty $B$, Pessayre D. Inhibition of mitochondrial $\beta$-oxidation as a mechanism of hepatotoxicity. Pharmacol Ther. 1995;67:101-54.

14. Girow LM, Freire V, Alonzo A, Caceres A. Ethnobotanical survey of the medicinal flora used by the Caribs of Guatemala. J Ethnopharmacol. 1991;34:143-87.

15. Guevarra AP, Espino MP, Chua C, Russel G. Anti-inflammatory principles of the leaves of Persea americana. Mill. Philipp J Sci. 1998;127:81-91.

16. Heimberg M, Weinstein I, Dishmon G, Dunkerley A. The action of carbon tetrachloride on the transport and metabolism of triglycerides and fatty acids by the isolated perfused rat liver and its relationship to the etiology of fatty liver. J Biol Chem. 1962;237:3623-7.

17. Honma T, Suda M. Changes in plasma lipo-proteins as toxicity markers for carbon tetrachloride, chloroform and dichloromethane. Ind Health. 1997;35: 519-31.

18. Kamalakkannan N, Rukkumani R, Viswanathan P, Rajasekharan KN, Menon VP. Effect of Curcumin and its analogue on lipids in carbon tetrachlorideinduced hepatotoxicity: a comparative study. Pharm Biol. 2005:43:460-6.

19. Kolawole OT, Kolawole SO, Adekunle AA, Olaniran IO. Methanol leaf extract of Persea americana protects rats against cholesterol-induced hyperlipidemia. Br J Med Med Res. 2012;2(2):235-42.

20. Lieber CS. Alcoholic liver disease: new insights on pathogenesis lead to new treatment. J Hepatol. 2000;32:113-28.

21. Mandal A, Karmakar R, Bandyopadhyay S, Chatterjee M. Antihepatotoxic potential of Trianthema portulacastrum in carbon tetrachloride-induced chronic hepatocellular injury in mice: reflection in haematological, histological and biochemical characteristics. Arch Pharm Res. 1998;21:223. https://doi.org/10.1007/BF02975279.

22. Manjunatha BK. Hepatoprotective activity of Pterocarpus santalinus L. f., an endangered medicinal plant. Indian J Pharmacol. 2006;38:25-8.

23. Mankani KL, Krishna V, Manjunatha BK, Vidya SM, Jagadeesh Singh SD, Manohara YN, Raheman A, Avinash KR. Evaluation of hepatoprotective activity of stem bark of Pterocarpus marsupium Roxb. Indian J Pharmacol. 2005;37:165-8

24. Mitra SK, Gopumadhavan S, Muralidhar TS, Anturlika SD, Sujatha MB. Effect of a herbomineral preparation D-400 in streptozotocin induced diabetic rats. J Ethnopharmacol. 1996:54:41-6.

25. Mollazadeh $\mathrm{H}$, Mahdian D, Hosseinzadeh $\mathrm{H}$. Medicinal plants in treatment of hypertriglyceridemia: a review based on their mechanisms and effectiveness. Phytomedicine. 2019;53:43-52.

26. Ojewole JAO, Amabeoku GJ. Anticonvulsant effect of Persea americana mill (Lauraceae) (avocado) leaf aqueous extract in mice. Phytother Res. 2006;20: 696-700.

27. Owolabi MA, Coker HAB, Jaja SI. Bioactivity of the phytoconstituents of the leaves of Persea americana. J Med Plant Res. 2010;4(12):1130-5.

28. Owolabi MA, Jaja SI, Coker HAB. Vasorelaxant action of aqueous extract of the leaves of Persea americana on isolated thoracic rat aorta. Fitoterapia. 2005:76:567-73.

29. Pencil D, Brattin WJ Jr, Glende EA Jr, Recknagel RO. Carbon tetrachloridedependent inhibition of lipid secretion by isolated hepatocytes: characterization and requirement for bioactivation. Biochem Pharmacol. 1984:33:2419-23.

30. Piriou A, Warnet JM, Jacqueson A, Claude JR, Truhaut R. Fatty liver induced by high doses of rifampicin in the rat: possible relation with an inhibition of RNA polymerases in eukaryotic cells. Arch Toxicol Suppl. 1979;2:333-7. 
31. Purit PE, Mangisah $L$, Suthama $N$. The effects of dietary supplementation of onion and garlic husk powder on protein, cholesterol, and fat of duck meat. In: Proceedings of International seminar on Livestock Production and Veterinary Technology. LPVT-2016; 2017. p. 422-7.

32. Recknagel RO, Lombardi B, Schotz MC. A new insight into the pathogenesis of carbon tetrachloride fat infiltration. Proc Soc Exp Biol Med. 1960;104:608-10.

33. Rodriguez-Carpena JG, Morcuende D, Estevez M. Avocado by-products as inhibitors of color deterioration and lipid and protein oxidation in raw porcine patties subjected to chilled storage. Meat Sci. 2011;89:166-73.

34. Seakins A, Robinson DS. The effect of administration of carbon tetrachloride on the formation of plasma lipoproteins in the rat. Biochem J. 1963;86:401-7.

35. Tabeshpour J, Razavi BM, Hosseinzadeh H. Effect of avocado Persea americana on metabolic syndrome: a comprehensive systematic review. Phytother Res. 2017;31:819-37.

36. Venukumar MR, Latha MS. Hepatoprotective effect of the Methanolic extract of Curculigo orchioides in $\mathrm{CCl}_{4}$-treated male rats. Indian J Pharmacol. 2002;34:269-75

37. Wang BJ, Liu CT, Tseng CY, Wu CP, Yu ZR. Hepatoprotective and antioxidant effects of Bupleurum kaoi Liu (Chao et Chuang) extract and its fractions fractionated using supercritical $\mathrm{CO} 2$ on $\mathrm{CCl}_{4}$-induced liver damage. Food Chem. Toxicol. 2004;42:609-17.

38. Weber LWD, Boll M, Stampfl A. Hepatotoxicity and mechanism of action of haloalkanes: carbon tetrachloride as a toxicological model. Crit Rev Toxicol. 2003;33:105-36.

\section{Publisher's Note}

Springer Nature remains neutral with regard to jurisdictional claims in published maps and institutional affiliations.

\section{Submit your manuscript to a SpringerOpen ${ }^{\circ}$ journal and benefit from:}

- Convenient online submission

- Rigorous peer review

- Open access: articles freely available online

- High visibility within the field

- Retaining the copyright to your article 